\title{
Calcium-activated chloride current expression in axotomized sensory neurons: what for?
}

\author{
Mathieu Boudes ${ }^{1,2,3}$ and Frédérique Scamps ${ }^{1 *}$ \\ 1 INSERM U-1051, Sensory Diseases, Neuro-plasticity and Therapy, Institut des Neurosciences de Montpellier, Montpellier, France \\ ${ }^{2}$ Lab of Ion Channel Research, Department of Cellular and Molecular Medicine, KU Leuven, Leuven, Belgium \\ ${ }^{3}$ Experimental Urology Lab, Department of Development and Regeneration, KU Leuven, Leuven, Belgium
}

\section{Edited by:}

Nikita Gamper, University

of Leeds, UK

\section{Reviewed by:}

Hailin Zhang, Hebei Medical

University, China

John Linley, Molecular Nociception

Group, UCL, UK

\section{*Correspondence:}

Frédérique Scamps, INM-Hôpital

St. Eloi, INSERM U-1051, 80 rue

Augustin Fliche, 34091 Montpellier

Cedex 5, France.

e-mail: frederique.scamps@

inserm.fr
Calcium-activated chloride currents ( $\mathrm{CaCCs}$ ) are activated by an increase in intracellular calcium concentration. Peripheral nerve injury induces the expression of $\mathrm{CaCCs}$ in a subset of adult sensory neurons in primary culture including mechano- and proprioceptors, though not nociceptors. Functional screenings of potential candidate genes established that Best1 is a molecular determinant for $\mathrm{CaCC}$ expression among axotomized sensory neurons, while Tmem16a is acutely activated by inflammatory mediators in nociceptors. In nociceptors, such $\mathrm{CaCC}$ are preferentially activated under receptor-induced calcium mobilization contributing to cell excitability and pain. In axotomized mechano- and proprioceptors, $\mathrm{CaCC}$ activation does not promote electrical activity and prevents firing, a finding consistent with electrical silencing for growth competence of adult sensory neurons. In favor of a role in the process of neurite growth, $\mathrm{CaCC}$ expression is temporally correlated to neurons displaying a regenerative mode of growth. This perspective focuses on the molecular identity and role of $\mathrm{CaCC}$ in axotomized sensory neurons and the future directions to decipher the cellular mechanisms regulating $\mathrm{CaCC}$ during neurite (re)growth.

Keywords: DRG, CaCC, bestrophin, regeneration, axotomy, electrical activity, membrane tension

\section{INTRODUCTION}

After peripheral nerve injury, sensory neurons switch from a transmitting mode to a regrowth mode. Axotomy of adult peripheral neurons induces rapid axon regeneration. This has been demonstrated in vivo (Tanaka et al., 1992; Jacob and McQuarrie, 1993) and in vitro (Smith and Skene, 1997; Lankford et al., 1998; Andre et al., 2003) where a conditioning lesion increases the ability of the associated primary afferent neuron to regenerate successfully. Molecular mechanisms responsible for this increased neuronal growth ability are accompanied by a shift in cellular organization, such as the appearance of growth cones at the proximal tip of the lesioned axons and the swelling of the neuronal cell body associated with a strong increase in cellular metabolism and protein synthesis (Makwana and Raivich, 2005). Transcriptomic analysis of gene expression following peripheral nerve injury has led to the identification of many injury-related and regenerationassociated genes encoding such as regulatory proteins including growth factor receptors and transcription factors (Araki et al., 2001; Costigan et al., 2002; Xiao et al., 2002; Mechaly et al., 2006).

Axotomy upregulates $\mathrm{Ca}^{2+}$ activated chloride current (CaCC) expression in sensory, sympathetic, and nodose neurons (Sanchez-Vives and Gallego, 1994; Lancaster et al., 2002; Andre et al., 2003). Using an in vitro model of regenerative growth, we have shown that a close relationship exists between the growth competence of sensory neurons and $\mathrm{CaCC}$ expression (Andre et al., 2003). In addition, its expression is limited to a subset of neurons including those of medium and large somatic diameter, i.e., the mechano- and proprioceptors. No expression was observed among small somatic diameter neurons, i.e., the nociceptors.

Under physiological conditions, the reversal potential of $\mathrm{Cl}^{-}$ currents is around $-40 \mathrm{mV}$ among most sensory neurons due to the expression and activity of an inwardly directed $\mathrm{Na}^{+}$$\mathrm{K}^{+}-2 \mathrm{Cl}^{-}$co-transporter, NKCC1 (Sung et al., 2000). This corresponds to an intracellular chloride concentration $\left(\left[\mathrm{Cl}^{-}\right]_{\mathrm{i}}\right)$ of sensory neurons amounting to $20-30 \mathrm{mM}$ (Alvarez-Leefmans et al., 1988) thus conferring a depolarizing effect of $\mathrm{Cl}^{-}$currents at resting potential. Following nerve injury, $\mathrm{Cl}^{-}$reversal potential shifts toward depolarized potentials reaching up to $20 \mathrm{mV}$ corresponding to a two to threefold increase in $\left[\mathrm{Cl}^{-}\right]_{\mathrm{i}}$ which increases further the $\mathrm{Cl}^{-}$current driving force relative to the resting potential (Pieraut et al., 2007). Thus, CaCC expressed in axotomized, regenerating sensory neurons is potentially suited to inducing membrane depolarization and triggering electrical activity. Several years ago, Scott et al. in their review on CaCC pointed out the complexity of defining a role for these channels presumed to have a variety of different functions depending on their co-localization with other channels and the type of physiological mechanism involved in raising the $\left[\mathrm{Ca}^{2+}\right]_{i}$ (Scott et al., 1995). Recently, the identification of several candidate genes for $\mathrm{CaCC}$ has also to be considered to define the complexity in their role (Duran et al., 2010). Indeed, besides a potential role in electrical activity, CaCC has also been shown to be involved in other cellular functions such as secretion, proliferation, and apoptosis (Kunzelmann et al., 2011). 


\section{BESTROPHIN-1: A MOLECULAR DETERMINANT FOR CaCC EXPRESSION AND PERIPHERAL NERVE REGENERATION CaCC AND BESTROPHIN-1 FUNCTIONALLY LINKED IN TRAUMATIZED SENSORY NEURONS}

Calcium-activated chloride channels are coded by a great diversity of genes. To date, research has identified four families of CaCC: the CLCA (Pauli et al., 2000), the bestrophin (Sun et al., 2002), the tweety (Suzuki and Mizuno, 2004) and the TMEM16 families (Caputo et al., 2008; Schroeder et al., 2008; Yang et al., 2008). Members of all four families have been found expressed in the DRG following nerve injury (Al-Jumaily et al., 2007; Boudes et al., 2009). CLCA proteins have high homology to known cell adhesion proteins and it is suggested that CLCA proteins modulate endogenous $\mathrm{Cl}^{-}$channels (Hartzell et al., 2005). While some doubt remains regarding the exact channel function of each of the proteins from the three other families, they are all still considered as putative chloride channels based on bioinformatics and functional data. This great diversity renders the exploration of their function difficult, due to the lack of specific pharmacological and molecular tools to inhibit each of the channels specifically. An elegant method to modulate gene expression by RNA interference using single-cell electroporation in cultured adult DRG neurons was developed to decipher the molecular nature of $\mathrm{CaCC}$ expressed in injured sensory neurons (Boudes et al., 2008). With a functional screening strategy, we demonstrated that among six candidates, only siRNA targeted against Best1 down-regulated CaCC expression in axotomized DRG neurons. Moreover, Bestrophin-1 overexpression with an expression plasmid generated $\mathrm{CaCC}$ with biophysical properties close to native currents in putative mechano- and proprioceptors (Boudes et al., 2009). However, no definitive conclusions could be drawn since Best1 knockout mice expressed a CaCC following in vivo peripheral nerve axotomy which could result from a functional compensation by Best 3 in the null mice.

\section{BESTROPHIN-1, A KEY PLAYER IN FUNCTIONAL NEURITE OUTGROWTH}

The genetic ablation of Bestrophin-1 (using both knockout mice and RNA interference strategies) induces a decrease in neurite outgrowth velocity in cultured injured sensory neurons (Boudes et al., unpublished result). It is noteworthy that Best3 compensation in the knock-out mice could not sustain neurite growth suggesting the importance of a subcellular localization for correct cellular functioning. Unfortunately, the lack of specific antibodies prevented to determine the cellular and subcellular localizations of Bestrophin-1 and 3, both in vitro and in vivo. Nevertheless, the observation of positive effects of Bestrophin-1 on neurite growth led us to check for any benefits to the functioning of nerve regeneration in vivo. The lack of a direct relationship between morphological data and functional studies, led us to use behavioral test to assess nerve fiber regeneration (de Medinaceli, 1995; Baptista et al., 2007). Following nerve injury, measuring the paw withdrawal threshold in response to mechanical stimulus using a series of graded von Frey filaments can assess the time for recovery of sensitivity to mechanoreceptors function. In agreement with studies in mice (Vogelaar et al., 2004), measurement of the withdrawal threshold before and after left sciatic nerve crush injury indicated that basal mechanical sensitivity needed 15 days to recover (12 mice). In a preliminary study, we observed that, following sciatic nerve crush, Best1 knockout mice display a roughly 5 days delay for recovery of basal sensibility (10 mice). This strongly indicates a slowing down of the functional outgrowth of a subset of afferent fibers.

Altogether, these data show that Bestrophin-1 is a positive player in the regenerative process of the mechanosensitive afferent fibers. The next and crucial challenge is to understand how $\mathrm{CaCC}$ is involved in the regeneration of injured sensory neurons.

\section{CaCC AND REGENERATION, HOW DOES IT WORK? REGENERATION, ELECTRICAL ACTIVITY AND CaCC, A TRIPTYCH?}

A recent study reported that loss of electrical activity following peripheral deafferentation is an important signal to trigger axon regrowth and that concordantly electrical activity strongly inhibits axon outgrowth in cultured adult sensory neurons (Enes et al., 2010). It is proposed that electrical silencing is an important cue in eliciting the conditioning effect on growth competence of adult DRG neurons. Consistent with this notion, no somatic sensations are experienced following peripheral nerve transection, except under certain circumstances when neuropathic pain is felt.

To address the role of $\mathrm{CaCC}$ in axotomized adult sensory neurons, we first postulated an involvement in the control of their electrical activity. This led us to analyze the calcium sensitivity of CaCC by simultaneously recording intracellular $\mathrm{Ca}^{2+}$ variation and electrophysiological measurements under opening of voltage gated $\mathrm{Ca}^{2+}$ channels, VGCCs. Surprisingly, CaCC displayed a rather low $\mathrm{Ca}^{2+}$ sensitivity such that one action potential was unable to mobilize enough $\mathrm{Ca}^{2+}$ to activate CaCC. In the same study, a train of action potentials was necessary to increase $\mathrm{Ca}^{2+}$ to levels sufficient to activate CaCC. Even under such conditions, the CaCC-induced membrane depolarization could be observed only provided that $\mathrm{K}^{+}$currents were partially inhibited (Hilaire et al., 2005a). Importantly, under high $\left[\mathrm{Cl}^{-}\right]_{\mathrm{i}}$ as determined in axotomized neurons $\left(\mathrm{E}_{\mathrm{rev}}\right.$ close to $-20 \mathrm{mV}$ ), once $\mathrm{K}^{+}$current inhibition had elicited firing activity, CaCC was able to progressively depolarize the resting membrane potential leading to $\mathrm{Na}^{+}$current inactivation and the consequent cessation of electrical activity. Afterwards, a progressive repolarization occurred due to the loss of $\mathrm{Ca}^{2+}$ entry through the VGCCs (among 13 recorded axotomized sensory neurons displaying an after-depolarization, six generated firing activity with progressively decreasing amplitude until membrane depolarization reached $-28 \pm 2 \mathrm{mV}$, a value close to $\mathrm{Cl}^{-}$reversal potential and sufficient to inactivate $\mathrm{Na}^{+}$channels. All neurons expressed CaCC without differences in amplitude). Although we never recorded spontaneous electrical activity in conditioned axotomized mechano- or proprioceptors, they did display a lower excitability threshold and a subset of them could fire action potentials under intracellular $\mathrm{Ca}^{2+}$ buffering, which prevented CaCC activation (Hilaire et al., 2005b). This last result confirms that a subset of axotomized neurons is more sensitive to fire; the molecular changes responsible for increased excitability under intracellular $\mathrm{Ca}^{2+}$ buffering remain to be determined. From these observations, it appears that activation of $\mathrm{CaCC}$ under intense electrical activity and $\mathrm{K}^{+}$current inhibition could induce a negative retro control on neuronal firing properties, therefore preventing unfavorable conditions for neurite regrowth. 
The source of $\mathrm{Ca}^{2+}$ to activate $\mathrm{CaCC}$ is not necessarily through the opening of VGCCs. Indeed, receptor-mediated intracellular $\mathrm{Ca}^{2+}$ mobilization is also known to activate CaCC (Scott et al., 1995). To demonstrate whether activation of CaCC could trigger electrical activity in axotomized sensory neurons, caffeine was used to mobilize $\mathrm{Ca}^{2+}$ stores. Consistent with other studies, caffeine activated CaCC as efficiently as VGCC and induced membrane depolarization. However, it never triggered electrical activity in axotomized sensory neurons (unpublished result). In fact, unless $\mathrm{K}^{+}$currents were inhibited, CaCC-induced membrane depolarization never reached a threshold able to trigger electrical activity.

Consistent with the concerted action of CaCC activation together with $\mathrm{K}^{+}$current inhibition on neuronal excitability, the bradykinin-elicited electrical activity observed among nociceptors was due to activation of CaCC together with inhibition of (Kv7) M-current. Interestingly, a lack of coupling between CaCC and VGCC in nociceptors observed in this study was suggested to be required in order to avoid a self-maintaining positive feedback loop. Indeed if $\mathrm{Ca}^{2+}$ influx through VGCC was to significantly activate $\mathrm{CaCC}$ (and inhibit M channels), this would then cause depolarization and further $\mathrm{Ca}^{2+}$ influx through VGCC and an amplification of the cycle (Liu et al., 2010). The authors concluded that in most small DRG neurons (in contrast to the medium/large ones), the coupling between VGCC and $\mathrm{CaCC}$ is minimal, which may suggest either poor spatial colocalization of CaCC and VGCC and/or a different molecular identity of CaCC in small compared with large DRG neurons. $\mathrm{CaCC}$ amplitude is clearly smaller in nociceptors (pA range) than in axotomized mechano-proprioceptors (nA range) which could be related to both cell size and different channel conductances (Hartzell et al., 2005). This difference in current density could also account for the outward rectification for CaCC-voltage relationships in nociceptors versus linear in axotomized mediumlarge neurons (Yang et al., 2008). Although both CaCCs were sensitive to niflumic acid and NPPB inhibition, DIDS had not effects in mechano- and proprioceptors (Andre et al., 2003). Consistent with a different type of $\mathrm{CaCC}$ expressed in nociceptors, the expression of TMEM16A is observed in the majority of small DRG neurons but not in large neurons (Yang et al., 2008). Tmem16a is functionally involved in bradykinin-induced CaCC among nociceptors (Liu et al., 2010), while Best1 accounts for $\mathrm{CaCC}$ expression in axotomized sensory neurons (Boudes et al., 2009). Interestingly, in a model of conditioning, the elongating mode of growth in vitro was activated only in the population of nociceptors that did not express calcitonin gene-related peptide $\left(\mathrm{CGRP}^{-}\right)$or bind isolectin $\mathrm{B} 4\left(\mathrm{IB}^{-}\right)$. In other words, a lower regenerative capacity was observed in unmyelinated peptidergic and non-peptidergic primary afferent neurons (Leclere et al., 2007; Kalous and Keast, 2010). It would be of interest to verify whether this subset of nociceptors do also express Tmem16a under axotomy.

From these studies, a possible role of large amplitude $\mathrm{CaCC}$ together with high $\left[\mathrm{Cl}^{-}\right]_{\mathrm{i}}$ in axotomized mechano- and proprioceptors would be to prevent the maintenance of intense electrical activity and thereby contribute to the electrical silencing necessary for growth competence.

\section{REGENERATION, MEMBRANE TENSION AND CaCC: THE ELECTRONEUTRAL HYPOTHESIS}

Mechanotransduction is the cellular mechanism by which cells, including neurons, sense and respond to their physical surroundings. Given the amphiphilic nature of phospholipids, neuritic expansion during growth is mainly achieved by inserting vesicles into pre-existing membranes at the growth cone (Pfenninger, 2009). This mechanism is highly demanding in energy and neurons need to counteract physical issues to achieve it. Indeed, growth cones deal with external and internal mechanical forces. Under in vitro conditions, intracellular positive forces, such as cytoskeleton polymerization and osmotic tension, are probably the main drivers for neurite growth (Geiger et al., 2009). Osmotic tension is induced under changes in the intracellular ionic concentration. An increase in ionic concentration or hypotonic extracellular solution promote rise in osmotic tension due to water entry leading to cell swelling. Conversely, a decrease in ionic concentration promotes a fall in osmotic tension due to water exit and leads to cell shrinkage.

There are no reports linking CaCC activation to cell swelling in neurons. A contribution from CaCC channels is, however, to be expected when volume regulation is associated with an increase in $\left[\mathrm{Ca}^{2+}\right]_{\mathrm{i}}$. Hypotonic extracellular solution induces $\left[\mathrm{Ca}^{2+}\right]_{\mathrm{i}}$ increase and triggers electrical activity in a subset of nociceptors and mechanoceptors, but not among most mechanoand proprioceptors (Viana et al., 2001; Alessandri-Haber et al., 2003; Haeberle et al., 2008). Cell specific expression of stretchsensitive, $\mathrm{Ca}^{2+}$ permeable channels, such TRPV4, accounted for these effects suggesting that volume regulatory mechanisms are electrically silent in the remaining neurons. Ionic channels, exchangers and co-transporters contribute to cell volume regulation (Hoffmann et al., 2009). Preferential activation of volumesensitive $\mathrm{K}^{+}$channels could prevent cell excitability. To date, nothing is known concerning the expression of $\mathrm{Ca}^{2+}$ permeable stretch channels in axotomized sensory neurons. Interestingly, GAP43 (growth-associated protein 43) a membrane-anchored neuronal protein up-regulated in axotomized dorsal root ganglia and positive regulator of axonal regeneration, is an osmosensory protein that augments $\left[\mathrm{Ca}^{2+}\right]_{\mathrm{i}}$ in response to hypotonicity (Caprini et al., 2003; Makwana and Raivich, 2005). Besides, it is reported that drosophila bestrophin-1 (dBest1) is dually activated by calcium and cell volume (Chien and Hartzell, 2007). Interestingly, volume-regulated anion current (VRAC) can be rescue with different mutants of dBest1 in drosophila S2 cells although bestrophins are unlikely to be the classical VRAC in mammalian cells (Chien and Hartzell, 2008). Altogether, these findings support that variation in cell tension through swelling could contribute to CaCC activation and to cell growth (Raucher and Sheetz, 2000).

Consistent with a role of membrane tension during neurite growth, we found that, in vitro, axotomized sensory neurons display more than a twofold increase in $\left[\mathrm{Cl}^{-}\right]_{\mathrm{i}}$ due to interleukin6-induced phosphorylation of NKCC1 (Slc12a2), an electroneutral cation-chloride co-transporter (Pieraut et al., 2007, 2011). This plasmalemmal ion transporter not only regulates the basal $\left[\mathrm{Cl}^{-}\right]_{\mathrm{i}}$ but also belongs to the set of molecules controlling osmotic force (O’Neill, 1999). Therefore, receptor-mediated chloride 
accumulation does indeed create a situation of osmotic tension, something which has been so far overlooked in neuronal physiology and pathophysiology. Osmotic tension needs to be controlled to avoid cell deterioration and the efflux of chloride ions at resting membrane potential through $\mathrm{CaCC}$ can be an option. We postulate that under activation of NKCC1, exit of $\mathrm{Cl}^{-}$through $\mathrm{CaCC}$ at resting membrane potential could be balanced with $\mathrm{K}^{+}$outflow induced by volume and/or voltage-activated $\mathrm{K}^{+}$currents, making CaCC effects electrically silent. Thus Slc12a2 and Best1 could belong to the set of genes involved in mechanotransduction through modification of the osmotic force.

Interestingly, we observed that preventing the rise in $\left[\mathrm{Cl}^{-}\right]_{\mathrm{i}}$ in axotomized sensory neurons in a low external $\mathrm{Cl}^{-}$concentration or using $\mathrm{NKCC}^{-/-}$mice, not only reduced neurite growth velocity (Pieraut et al., 2007) but also prevented $\mathrm{CaCC}$ expression: $27 \%(10 / 37)$ under low external $\mathrm{Cl}^{-}$and $26 \%(9 / 35)$ in $\mathrm{NKCC1}^{-/-}$sensory neurons compared to $66 \%$ (25/42). This thus highlighted a link between $\left[\mathrm{Cl}^{-}\right]_{\mathrm{i}}$ regulation and $\mathrm{CaCC}$ expression during neurite growth. We propose that the osmotic force associated with volume increase due to NKCC1-induced chloride accumulation could be a cellular mechanism contributing to neurite growth velocity. Envisaging neuronal $\mathrm{Ca}^{2+}$-activated chloride channels involved in electrically silent cellular mechanisms to regulate growth is fascinating and needs to be explored.

\section{PERSPECTIVES}

A major pitfall in the study of $\mathrm{CaCC}$ expressed in regenerating sensory neurons is the actual localization and source of $\mathrm{Ca}^{2+}$. Many studies have addressed the role of $\mathrm{Ca}^{2+}$ during developmental neurite growth and synaptic plasticity (Zheng and Poo, 2007). To our knowledge however, the determination of $\mathrm{Ca}^{2+}$ transients during the regenerative growth of sensory neurons has never been performed. To address this important issue, time lapse recordings of spontaneous $\mathrm{Ca}^{2+}$ with $\mathrm{Ca}^{2+}$ sensitive probes will be necessary. It will also be of interest to identify $\mathrm{Cl}^{-}$variation with $\mathrm{Cl}^{-}$sensitive fluorescent probes (Chub et al., 2006; Bregestovski et al., 2009) and tentatively correlate, both temporally and spatially, each event.

Despite the identification of Best1 as a molecular determinant of $\mathrm{CaCC}$ in medium/large diameter sensory neurons, the

\section{REFERENCES}

Alessandri-Haber, N., Yeh, J. J., Boyd, A. E., Parada, C. A., Chen, X., Reichling, D. B., and Levine, J. D. (2003). Hypotonicity induces TRPV4-mediated nociception in rat. Neuron 39, 497-511.

Al-Jumaily, M., Kozlenkov, A., Mechaly, I., Fichard, A., Matha, V., Scamps, F., Valmier, J., and Carroll, P. (2007). Expression of three distinct families of calcium-activated chloride channel genes in the mouse dorsal root ganglion. Neurosci. Bull. 23, 293-299.

Alvarez-Leefmans, F. J., Gamino, S. M., Giraldez, F., and Nogueron, I. (1988). Intracellular chloride regulation in amphibian dorsal root ganglion neurones studied with ion-selective microelectrodes. J. Physiol. 406, 225-246.

Andre, S., Boukhaddaoui, H., Campo, B., Al-Jumaily, M., Mayeux, V., Greuet, D., Valmier, J., and Scamps, F. (2003). Axotomy-induced expression of calcium-activated chloride current in subpopulations of mouse dorsal root ganglion neurons. J. Neurophysiol. 90, 3764-3773.

Araki, T., Nagarajan, R., and Milbrandt, J. (2001). Identification of genes induced in peripheral nerve after injury. Expression profiling and novel gene discovery. J. Biol. Chem. 276, 34131-34141.

Best $1^{-/-}$mice did express a CaCC which disallowed any definitive conclusions to be drawn concerning the role of $\mathrm{CaCC}$. Moreover, Bestrophin-1 is probably not the only molecular partner involved in $\mathrm{CaCC}$ expression as its overexpression in nociceptors did not result in a functional $\mathrm{Cl}^{-}$current. Identification of the other molecular partners or regulators could lead to the design of new tools enabling a better understanding of CaCC function.

The membrane tension hypothesis could be tested with the use of biophysical techniques such as atomic force microscopy (AFM) (Ricci et al., 2011). AFM has become a well-used tool for high resolution imaging of biological materials. Surface forces and surface properties (hydrophobicity, elasticity) could be measured on a nanoscale providing spatially -resolved maps of the nanomechanical characteristics of growing sensory neurons from NKCC1 or Bestrophin-1 knockout mice.

The lack of growth competence among a subset of nociceptors, in particular the IB4-positive neurons together with their known vulnerability to peripheral nerve injury could be attributed in part to their Tmem16a expression and propensity to fire action potentials. While IB4-labeled neurons do fail to synthesize some proteins involved in axonal regeneration (Leclere et al., 2007), the development of intense electrical activity may also participate. Analyzing neurite growth competence in Tmem $16 a^{-1-}$ neurons should help clarify this issue.

The concomitant appearance of a high $\left[\mathrm{Cl}^{-}\right]_{\mathrm{i}}$ in central neurons (Represa and Ben-Ari, 2005) and the expression of CaCC occur during the development of sensory (Bernheim et al., 1989; Currie and Scott, 1992) and spinal neurons (Hussy, 1991, 1992) and in injury models (Nabekura et al., 2002; Andre et al., 2003; Pieraut et al., 2007). Therefore, we can postulate a role of Bestrophin-1 in these physio and/or physiopathological processes. Functional studies focused on developmental and injured models may be able to decipher a universal growth mechanism which would be something worth knowing!

\section{ACKNOWLEDGMENTS}

We would like to thank the Association Française contre les Myopathies (AFM) for financial support. Mathieu Boudes is a Marie Curie fellow.

Baptista, A. F., Gomes, J. R., Oliveira, J. T., Santos, S. M., Vannier-Santos, M. A., and Martinez, A. M. (2007). A new approach to assess function after sciatic nerve lesion in the mouse - adaptation of the sciatic static index. J. Neurosci. Methods 161, 259-264.

Bernheim, L., Bader, C. R., Bertrand, D., and Schlichter, R. (1989). Transient expression of a $\mathrm{Ca}^{2+}$. activated $\mathrm{Cl}^{-}$current during development of quail sensory neurons. Dev. Biol. 136, 129-139.

Boudes, M., Pieraut, S., Valmier, J., Carroll, P., and Scamps, F. (2008). Single-cell electroporation of adult sensory neurons for gene screening with RNA interference mechanism. J. Neurosci. Methods 170, 204-211.

Boudes, M., Sar, C., Menigoz, A., Hilaire, C., Pequignot, M. O., Kozlenkov, A., Marmorstein, A., Carroll, P., Valmier, J., and Scamps, F. (2009). Bestl is a gene regulated by nerve injury and required for $\mathrm{Ca}^{2+}$-activated $\mathrm{Cl}^{-}$ current expression in axotomized sensory neurons. J. Neurosci. 29, 10063-10071.

Bregestovski, P., Waseem, T., and Mukhtarov, M. (2009). Genetically encoded optical sensors for monitoring of intracellular chloride and chloride-selective channel activity. 
Front. Mol. Neurosci. 2:15. doi: 10.3389/neuro.02.015.2009

Caprini, M., Gomis, A., Cabedo, H., Planells-Cases, R., Belmonte, C., Viana, F., and Ferrer-Montiel, A. (2003). GAP43 stimulates inositol trisphosphate-mediated calcium release in response to hypotonicity. EMBO J. 22, 3004-3014.

Caputo, A., Caci, E., Ferrera, L., Pedemonte, N., Barsanti, C., Sondo, E., Pfeffer, U., Ravazzolo, R., Zegarra-Moran, O., and Galietta, L. J. (2008). TMEM16A, a membrane protein associated with calciumdependent chloride channel activity. Science 322, 590-594.

Chien, L. T., and Hartzell, H. C. (2007). Drosophila bestrophin-1 chloride current is dually regulated by calcium and cell volume. J. Gen. Physiol. 130, 513-524.

Chien, L. T., and Hartzell, H. C. (2008). Rescue of volume-regulated anion current by bestrophin mutants with altered charge selectivity. J. Gen. Physiol. 132, 537-546.

Chub, N., Mentis, G. Z., and O'Donovan, M. J. (2006). Chloridesensitive MEQ fluorescence in chick embryo motoneurons following manipulations of chloride and during spontaneous network activity. J. Neurophysiol. 95, 323-330.

Costigan, M., Befort, K., Karchewski, L., Griffin, R. S., D’Urso, D., Allchorne, A., Sitarski, J., Mannion, J. W., Pratt, R. E., and Woolf, C. J. (2002). Replicate high-density rat genome oligonucleotide microarrays reveal hundreds of regulated genes in the dorsal root ganglion after peripheral nerve injury. $B M C$ Neurosci. 3, 16.

Currie, K. P., and Scott, R. H. (1992). Calcium-activated currents in cultured neurones from rat dorsal root ganglia. Br. J. Pharmacol. 106, 593-602.

de Medinaceli, L. (1995). Interpreting nerve morphometry data after experimental traumatic lesions. J. Neurosci. Methods 58, 29-37.

Duran, C., Thompson, C. H., Xiao, Q., and Hartzell, H. C. (2010). Chloride channels: often enigmatic, rarely predictable. Annu. Rev. Physiol. 72, 95-121.

Enes, J., Langwieser, N., Ruschel, J., Carballosa-Gonzalez, M. M., Klug, A., Traut, M. H., Ylera, B., Tahirovic, S., Hofmann, F., Stein, V., Moosmang, S., Hentall, I. D., and Bradke, F. (2010). Electrical activity suppresses axon growth through $\mathrm{Ca}(\mathrm{v}) 1.2$ channels in adult primary sensory neurons. Curr. Biol. 20, 1154-1164.

Geiger, B., Spatz, J. P., and Bershadsky, A. D. (2009). Environmental sensing through focal adhesions. Nat. Rev. Mol. Cell Biol. 10, 21-33.

Haeberle, H., Bryan, L. A., Vadakkan, T. J., Dickinson, M. E., and Lumpkin, E. A. (2008). Swelling-activated $\mathrm{Ca}^{2+}$ channels trigger $\mathrm{Ca}^{2+}$ signals in Merkel cells. PLoS One 3:e1750. doi: 10.1371/journal.pone.0001750

Hartzell, C., Putzier, I., and Arreola, J. (2005). Calcium-activated chloride channels. Annu. Rev. Physiol. 67, 719-758.

Hilaire, C., Campo, B., Andre, S., Valmier, J., and Scamps, F. (2005a). $\mathrm{K}(+)$ current regulates calciumactivated chloride current-induced after depolarization in axotomized sensory neurons. Eur. J. Neurosci. 22, 1073-1080.

Hilaire, C., Inquimbert, P., Al-Jumaily, M., Greuet, D., Valmier, J., and Scamps, F. (2005b). Calcium dependence of axotomized sensory neurons excitability. Neurosci. Lett. 380, 330-334.

Hoffmann, E. K., Lambert, I. H., and Pedersen, S. F. (2009). Physiology of cell volume regulation in vertebrates. Physiol. Rev. 89, 193-277.

Hussy, N. (1991). Developmental change in calcium-activated chloride current during the differentiation of Xenopus spinal neurons in culture. Dev. Biol. 147, 225-238.

Hussy, N. (1992). Calcium-activated chloride channels in cultured embryonic Xenopus spinal neurons. J. Neurophysiol. 68, 2042-2050.

Jacob, J. M., and McQuarrie, I. G. (1993). Acceleration of axonal outgrowth in rat sciatic nerve at one week after axotomy. J. Neurobiol. 24, 356-367.

Kalous, A., and Keast, J. R. (2010). Conditioning lesions enhance growth state only in sensory neurons lacking calcitonin generelated peptide and isolectin B4-binding. Neuroscience 166, 107-121.

Kunzelmann, K., Kongsuphol, P., Chootip, K., Toledo, C., Martins, J. R., Almaca, J., Tian, Y., Witzgall, R., Ousingsawat, J., and Schreiber, R. (2011). Role of the $\mathrm{Ca}^{2+}$-activated $\mathrm{Cl}^{-}$channels bestrophin and anoctamin in epithelial cells. Biol. Chem. 392, 125-134.

Lancaster, E., Oh, E. J., Gover, T., and Weinreich, D. (2002). Calcium and calcium-activated currents in vagotomized rat primary vagal afferent neurons. J. Physiol. 540, 543-556.
Lankford, K. L., Waxman, S. G., and Kocsis, J. D. (1998). Mechanisms of enhancement of neurite regeneration in vitro following a conditioning sciatic nerve lesion. J. Comp. Neurol. 391, 11-29.

Leclere, P. G., Norman, E., Groutsi, F., Coffin, R., Mayer, U., Pizzey, J., and Tonge, D. (2007). Impaired axonal regeneration by isolectin B4-binding dorsal root ganglion neurons in vitro. J. Neurosci. 27, 1190-1199.

Liu, B., Linley, J. E., Du, X., Zhang, X., Ooi, L., Zhang, H., and Gamper, N. (2010). The acute nociceptive signals induced by bradykinin in rat sensory neurons are mediated by inhibition of M-type $\mathrm{K}^{+}$channels and activation of $\mathrm{Ca}^{2+}$-activated $\mathrm{Cl}^{-}$channels. J. Clin. Invest. 120, 1240-1252.

Makwana, M., and Raivich, G. (2005) Molecular mechanisms in successful peripheral regeneration. FEBS $J$. 272, 2628-2638.

Mechaly, I., Bourane, S., Piquemal, D., Al-Jumaily, M., Venteo, S., Puech, S., Scamps, F., Valmier, J., and Carroll, P. (2006). Gene profiling during development and after a peripheral nerve traumatism reveals genes specifically induced by injury in dorsal root ganglia. Mol. Cell. Neurosci. 32, 217-229.

Nabekura, J., Ueno, T., Okabe, A., Furuta, A., Iwaki, T., ShimizuOkabe, C., Fukuda, A., and Akaike, N. (2002). Reduction of KCC2 expression and GABAA receptormediated excitation after in vivo axonal injury. J. Neurosci. 22, 4412-4417.

O’Neill, W. C. (1999). Physiological significance of volume-regulatory transporters. Am. J. Physiol. 276, C995-C1011.

Pauli, B. U., Abdel-Ghany, M., Cheng, H. C., Gruber, A. D., Archibald, H. A., and Elble, R. C. (2000). Molecular characteristics and functional diversity of CLCA family members. Clin. Exp. Pharmacol. Physiol. 27, 901-905.

Pfenninger, K. H. (2009). Plasma membrane expansion: a neuron's Herculean task. Nat. Rev. Neurosci. 10, 251-261.

Pieraut, S., Lucas, O., Sangari, S., Sar, C., Boudes, M., Bouffi, C., Noel, D., and Scamps, F. (2011). An autocrine neuronal interleukin6 loop mediates chloride accumulation and NKCC1 phosphorylation in axotomized sensory neurons. J. Neurosci. 31, 13516-13526.
Pieraut, S., Laurent-Matha, V., Sar, C., Hubert, T., Mechaly, I., Hilaire, C. Mersel, M., Delpire, E., Valmier, J., and Scamps, F. (2007). NKCC1 phosphorylation stimulates neurite growth of injured adult sensory neurons. J. Neurosci. 27, 6751-6759.

Raucher, D., and Sheetz, M. P. (2000). Cell spreading and lamellipodial extension rate is regulated by membrane tension. J. Cell Biol. 148, 127-136.

Represa, A., and Ben-Ari, Y. (2005). Trophic actions of GABA on neuronal development. Trends Neurosci. 28, 278-283.

Ricci, D., Grattarola, M., and Tedesco, M. (2011). The growth cones of living neurons probed by the atomic force microscope. Methods Mol. Biol. 736, 243-257.

Sanchez-Vives, M. V., and Gallego, R. (1994). Calcium-dependent chloride current induced by axotomy in rat sympathetic neurons. J. Physiol. 475, 391-400.

Schroeder, B. C., Cheng, T., Jan, Y. N., and Jan, L. Y. (2008). Expression cloning of TMEM16A as a calciumactivated chloride channel subunit. Cell 134, 1019-1029.

Scott, R. H., Sutton, K. G., Griffin, A., Stapleton, S. R., and Currie, K. P. (1995). Aspects of calciumactivated chloride currents: a neuronal perspective. Pharmacol. Ther. 66, 535-565.

Smith, D. S., and Skene, J. H. (1997). A transcription-dependent switch controls competence of adult neurons for distinct modes of axon growth. J. Neurosci. 17, 646-658.

Sun, H., Tsunenari, T., Yau, K. W., and Nathans, J. (2002). The vitelliform macular dystrophy protein defines a new family of chloride channels. Proc. Natl. Acad. Sci. U.S.A. 99, 4008-4013.

Sung, K. W., Kirby, M., McDonald, M. P., Lovinger, D. M., and Delpire, E. (2000). Abnormal GABAA receptor-mediated currents in dorsal root ganglion neurons isolated from $\mathrm{Na}-\mathrm{K}-2 \mathrm{Cl}$ cotransporter null mice. J. Neurosci. 20, 7531-7538.

Suzuki, M., and Mizuno, A. (2004). A novel human $\mathrm{Cl}(-)$ channel family related to Drosophila flightless locus. J. Biol. Chem. 279, 22461-22468.

Tanaka, K., Zhang, Q. L., and Webster, H. D. (1992). Myelinated fiber regeneration after sciatic nerve crush: morphometric observations in young adult and aging mice and the effects of macrophage suppression and conditioning lesions. Exp. Neurol. 118, 53-61. 
Viana, F., de la Pena, E., Pecson, B., Schmidt, R. F., and Belmonte, C. (2001). Swelling-activated calcium signalling in cultured mouse primary sensory neurons. Eur. J. Neurosci. 13, $722-734$.

Vogelaar, C. F., Vrinten, D. H., Hoekman, M. F., Brakkee, J. H., Burbach, J. P., and Hamers, F. P. (2004). Sciatic nerve regeneration in mice and rats: recovery of sensory innervation is followed by a slowly retreating neuropathic painlike syndrome. Brain Res. 1027, 67-72.
Xiao, H. S., Huang, Q. H., Zhang, F. X., Bao, L., Lu, Y. J., Guo, C., Yang, L., Huang, W. J., Fu, G., Xu, S. H., Cheng, X. P., Yan, Q., Zhu, Z. D., Zhang, X., Chen, Z., and Han, Z. G. (2002). Identification of gene expression profile of dorsal root ganglion in the rat peripheral axotomy model of neuropathic pain. Proc. Natl. Acad. Sci. U.S.A. 99, 8360-8365.

Yang, Y. D., Cho, H., Koo, J. Y., Tak, M. H., Cho, Y., Shim, W. S., Park, S. P., Lee, J., Lee, B., Kim, B. M., Raouf, R., Shin, Y. K., and Oh, U. (2008). TMEM16A confers receptor-activated calciumdependent chloride conductance. Nature 455, 1210-1215.

Zheng, J. Q., and Poo, M. M. (2007). Calcium signaling in neuronal motility. Annu. Rev. Cell Dev. Biol. 23, 375-404.

Conflict of Interest Statement: The authors declare that the research was conducted in the absence of any commercial or financial relationships that could be construed as a potential conflict of interest.
Received: 09 January 2012; accepted: 02 March 2012; published online: 22 March 2012.

Citation: Boudes $M$ and Scamps $F$ (2012) Calcium-activated chloride current expression in axotomized sensory neurons: what for? Front. Mol. Neurosci. 5:35. doi: 10.3389/fnmol.2012.00035 Copyright (c) 2012 Boudes and Scamps. This is an open-access article distributed under the terms of the Creative Commons Attribution Non Commercial License, which permits non-commercial use, distribution, and reproduction in other forums, provided the original authors and source are credited. 